\title{
Rzecz o górnołużyckich zdrobnieniach - ujęcie systemowe i tekstologiczne
}

\author{
Małgorzata Milewska-Stawiany, Górnołużyckie deminutywa \\ w systemie językowym i tekście, Wydawnictwo Uniwersytetu \\ Gdańskiego, Gdańsk 2012, 428 s.
}

Małgorzata Milewska-Stawiany od ponad dziesięciu lat zgłębia problem górnołużyckiego słowotwórstwa, w tym zwłaszcza trudną (wbrew pozorom) kategorię słowotwórczą deminutywów. Owocem jej żmudnej i wyjątkowo skrupulatnej pracy jest monografia Górnołużyckie deminutywa $w$ systemie językowym $i$ tekście. Książka wypełnia lukę w opracowaniach z zakresu słowotwórstwa języka górnołużyckiego. Podejmowane przez autorkę zagadnienie jest ważne, a przy tym wysoce specjalistyczne. Pomimo że omawiana pozycja dotyczy jedynie języka górnołużyckiego, może okazać się przydatna dla wszystkich badaczy zajmujących się słowotwórstwem i stylistyką, zwłaszcza w ujęciu konfrontatywnym.

W pierwszym rozdziale została przedstawiona autorska koncepcja analizy kategorii deminutywów. Za nadrzędne kryterium podziału odrzeczownikowych górnołużyckich derywatów zdrobniałych badaczka przyjmuje funkcję formantu. Odwołując się do ustaleń Alicji Nagórko, wyodrębnia, obok funkcji semantycznej, także funkcję pragmatyczną formantów deminutywnych, co rozszerza spektrum analizy derywacji deminutywnej o takie problemy, jak: stopień i rodzaj ekspresywności, wyrażanie ocen i emocjonalnego nastawienia nadawcy za pomocą odpowiednich środków słowotwórczych, stylistyczne efekty derywacji. Na uwagę zatem zasługuje proponowany przez autorkę sposób klasyfikacji deminutywów na: „1. Derywaty deminutywne modyfikacyjne, w których formant pełni funkcję semantyczną jakościową (...); 2. Derywaty deminutywne pragmatyczne, w których formant pełni funkcję pragmatyczną. Znak deminutywności jest tylko kwalitatywny, polega na wyrażaniu subiektywnych treści 
emotywno-oceniających nadawcy wypowiedzi wobec danego obiektu (...); 3. Derywaty deminutywne modyfikacyjno-pragmatyczne, w których znak deminutywności jest kwantytatywny i kwalitatywny zarazem, a formant pełni funkcję jakościową i pragmatyczną (...); 4. Derywaty deminutywne mutacyjne, w których formant pełni funkcję semantyczną przedmiotową, a znak deminutywności jest tylko pośrednio kwantytatywny" (s. 32-35). Takie ujęcie problematyki kategorii słowotwórczej zdrobnień jest niewątpliwym novum w badaniach slawistycznych.

W rozdziale pierwszym Metodologia a stan badań autorka deklaruje wyłączenie z obszaru badań deminutywów zleksykalizowanych. W tym kontekście niezupełnie jest dla mnie jasne kryterium zaliczenia do klasy deminutywów wyrazu 'nitka' w dwóch frazeologizmach, w których to rzekome zdrobnienie miałoby „podkreślać przede wszystkim ekspresję wypowiedzi" (s. 340). Chodzi o frazeologizmy: červjena nitka (w znaczeniu: „myśl przewodnia”), nitku přasć z někim (w znaczeniu: „być z kimś w bliskiej, przyjacielskiej relacji”). Tu zaznaczam, że wznowiony w 2005 roku Prawopisny słownik hornjoserbsko-němski wskazuje wyrazy „nić”, „nitka” jako synonimy i przy tym drugim nie wystąpił kwalifikator 'dim.', stosowany konsekwentnie w odniesieniu do formacji deminutywnych.

W swoim opracowaniu autorka stosuje założenia synchronicznego słowotwórstwa strukturalno-semantycznego, w niezbędnym zakresie uwzględnia także aspekt diachroniczny. W drugim rozdziale Deminutywa w górnotużyckim systemie językowym analizie poddano materiał słownikowy. Praca odznacza się bardzo starannym opisem zależności morfonologicznych, determinujących łączliwość formantów deminutywnych z tematami słowotwórczymi. Małgorzata Milewska-Stawiany rozpatruje jednak deminutywa górnołużyckie nie tylko ze względu na podstawowe parametry, wykorzystywane w klasycznych opracowaniach słowotwórstwa (opis inwentarza formantów deminutywnych, ich dystrybucji i produktywności, łączliwość formantów z tematami słowotwórczymi), ale dokonuje starannej i szczegółowej analizy kwantytatywnej. Solidnie opracowany aspekt ilościowy towarzyszy opisowi derywatów zarówno w drugim - Deminutywa w górnołużyckim systemie językowym, jak i trzecim rozdziale monografii - Funkcjonowanie deminutywów w tekście. Szczególnie cenny wydaje się właśnie rozdział trzeci, w którym podjęto problem funkcjonowania zdrobnień górnołużyckich w wybranych, różnych gatunkowo tekstach (pieśni i bajki 
ludowe, utwory Jakuba Barta-Ćišinskiego, publicystyka). Mechanizm tworzenia deminutywów w językach słowiańskich można uznać za zbadany, jednak funkcja, jaką pełnią one w konkretnym tekście i w konkretnej wypowiedzi, wciąż nie jest dobrze znana. Ta część monografii przynosi pierwszą na gruncie slawistycznym tak obszerną i szczegółową próbę systematyzacji deminutywów z punktu widzenia pragmatyki językowej. Badania poczynione na rzeczownikach zdrobniałych $\mathrm{w}$ tekstach górnołużyckich pieśni i bajek ludowych, a także w poezji Jakuba Barta-Ćišinskiego, pozwoliły na sformułowanie wniosku o przeważającej funkcji ekspresywnej i stylistycznej tych derywatów. Autorka uważa, że w badaniu zdrobnień ważne jest uwzględnienie kontekstu zewnętrznego. $Z$ tego punktu widzenia stara się rozpatrywać omawiane derywaty, opisując ich funkcjonowanie w tekstach publicystycznych. W tym miejscu jednak czytelnik odczuwa pewien niedosyt. Podrozdział na temat deminutywów w publicystyce górnołużyckiej, który z punktu widzenia językoznawstwa synchronicznego mógłby przynieść najbardziej interesujące rezultaty, został potraktowany dość zdawkowo, zamknięty w kilkunastu zaledwie stronach tekstu i przede wszystkim oparty na stosunkowo skromnym korpusie, obejmującym wydania dziennika „Serbske Nowiny” jedynie ze stycznia 2005 roku. Z kolei fragmenty pracy dotyczące klas semantycznych deminutywów obfitują w interesujące spostrzeżenia i fakty, odnoszące się zarówno do materiału słownikowego, jak i badań tekstologicznych.

Lektura monografii skłania odbiorcę także do sformułowania wątpliwości. Rodzi się pytanie, na ile prezentowany w pracy M. Milewskiej-Stawiany opis deminutywów górnołużyckich prezentuje aktualny ,podsystem deminutywny górnołużyckiego systemu słowotwórczego” (s. 9). Badania skupione na materiale językowym pozyskanym z szybko starzejących się, a w przypadku języka górnołużyckiego wręcz przestarzałych słowników (od wydania najnowszego z nich upłynęły prawie dwa pokolenia) oraz tekstów o walorach artystycznych (pieśni i bajek ludowych, poezji tworzonej na przełomie XIX i XX wieku), nie mogą dostarczyć aktualnych danych. Wiele $\mathrm{z}$ wymienionych w pracy zdrobnień należy zapewne do pasywnego zasobu leksykalnego. Dlatego raz jeszcze zwrócę uwagę na marginalne potraktowanie korpusu najnowszych tekstów publicystycznych, które mogłyby stanowić źródło wiedzy na temat współczesnego podsystemu deminutywnego języka górnołużyckiego. 
Na koniec pragnę się podzielić refleksją, do której zainspirowała mnie lektura pracy M. Milewskiej-Stawiany. Czy na podstawie wybranego korpusu najnowszych tekstów w języku górnołużyckim (np. tekstów piosenek, wierszy, czytanek dla dzieci wykorzystywanych w łużyckich przedszkolach w ramach modelowego programu „Witaj”; w większym korpusie tekstów publicystycznych i in.) udałoby się dostrzec jakiekolwiek wpływy bilingwizmu Łużyczan (np. kalkowanie struktur deminutywnych) na podsystem deminutywny języka górnołużyckiego? Tego typu dane wydają się niezwykle interesujące dla wielu specjalistów językoznawstwa synchronicznego.

Natalia Dtugosz 